\title{
PENERAPAN AKUNTABILITAS ANGGARAN UNTUK PENGUKURAN EFISIENSI DAN EFEKTIVITAS RENCANA ANGGARAN BIAYA (Studi Kasus pada PT. PELINDO Kantor Cabang Pulau Baii Bengkulu)
}

\author{
Asa'd \\ Email : asadamirhasan@yahoo.co.id
}

\begin{abstract}
ABSTRAK
Asa'd; PT Pelindo merupakan BUMN yang bergerak di bidang transportasi laut.Perusahaan. Seperti juga perusahaan yang bergerak dalam bidang transportasi lainnya di Indonesia, kenaikan harga BBM sangat mempengaruhi PT Pelindo, yang menyebabkan komponen biaya BBM meningkat menjadi $46,12 \%$ dari total biaya perkapalan. Oleh karena itu, perusahaan berusaha meningkatkan efisiensi di segala aspek, serta meningkatkan pengawasan internal untuk mengelola sisi biaya secara ketat. Penerapan akuntanbility mampu mendorong perusahaan guna mencapai tujuan tersebut melalui pengendalian biaya. Berdasakan latar belakang tersebut, maka tujuan penelitian ini adalah melakukan riset mengenai penerapan akuntanbility dalam mencapai pengendalian biaya.Penelitian ini menggunakan pendekatan kualitatif. Penelitian ini juga menggunakan studi pustaka dan wawancara dengan staf bagian keuangan pada PT. Pelindo Cabang Pulau Baai Bengkulu untuk memperoleh data. Metode analisis dari penelitian ini adalah dengan membandingkan penerapan akuntanbility dan pengendalian biaya yang diperoleh dari studi kasus.Dari hasil penelitian pada PT Pelindo Cabang Pulau Baai Bengkulu, perusahaan tersebut belum menerapkan akuntanbility dengan cukup baik, hal ini dapat diketahui dengan adanya beberapa syarat-syarat dan karakteristik yang belum dipenuhi. Perusahaan juga belum menjalankan pengendalian biaya dengan baik, hal ini dapat dilihat dari adanya analisis terhadap penyimpangan biaya yang belum dilakukan. Pengelolaan anggaran pada PT. Pelindo Cabang Pulau Baai Bengkulu cukup efektif dan efisien.
\end{abstract}

\begin{abstract}
Asa'd; PT Pelindo constitute of BUMN that have a range in sea transportation field. As well as the other company in Indonesia that have a range in transportation, the rise of BBM price can make an impact for PT Pelindo, which caused BBM price component rise until 46,12\% from the price total of shipping. Therefore, company try to increase the effeciency in every each of aspect, also increasing internal supervision to manage cost side with tight. Accountability application can encourage the company to achieve the purpose through cost control. Based from the background, the purpose of this observation is make a research about accountability application in reach of cost control. This observation use qualitative approach. This observation also literature and interview with financial staff from PT Pelindo Pulau Baii Branch Office Bengkulu to get the Data. The analysis method from the observation is comparing accountability application and cost control that obtainable from case study. Based on the result of PT Pelindo Pulau Baii Branch office Bengkulu, the company not yet to apply a good accountability, it is knew from presence some requirements and characterization which not yet to filled. The company also not yet to run the cost control in good way, this can see from the analysis presence against of cost digression which not implemented. Budget management in PT Pelindo Pulai Baii Branch office Bengkulu is adequate in effective and efficient.
\end{abstract}

Key words: Accountability Budget, Effectiveness and Effeciency.

\section{PENDAHULUAN}

Indonesia sebagai salah satu Negara yang terdiri atas bermacam pulau menyebabkan diperlukannya pengembangan sarana transportasi untuk menunjang aktivitas perekonomian. 
Sarana transportasi yang ada dimanfaatkan untuk mendistribusikan barang dan melayani jasa pengangkutan orang, dari satu tempat ke tempat yang lain untuk tujuan tertentu.

Menanggapi kebutuhan akan sarana transportasi, maka banyak bermunculan penyedia layanan jasa transportasi, baik itu transportasi darat, laut maupun udara. Semuanya berusaha menempatkan diri menjadi yang terbaik untuk mencapai tujuannya, yaitu untuk memperoleh laba dan memberikan layanan yang optimal. Oleh karena itu persaingan yang ketat pun tidak dapat dihindarkan demi mempertahankan dan meningkatkan kelangsungan hidup perusahaan.

Pelni, sebuah perusahaan pelayaran antar pulau milik Negara yang berdiri pada tahun 1950. Selanjutnya pada tahun 1975 statusnya berubah menjadi sebuah PT (Persero) sampai sekarang. Sejak tahun 2000, pendapatan Pelni dari penumpang kapalnya telah mengalami penurunan karena kehadiran pesawat-pesawat yang secara cepat telah mengambil alih hampir semua penumpang Pelni. Kesulitan lain yang dihadapi berkaitan dengan meningkatnya biaya operasi kapal secara tajam menyusul dihapuskannya subsidi bahan bakar mesin kapal sedangkan persaingan usaha semakin ketat. Dengan keterbatasan pada sisi penerimaan tersebut, upaya yang ada dipusatkan untuk peningkatan efisiensi di segala aspek, serta peningkatan pengendalian untuk mengelola sisi biaya secara ketat.

Demi kelangsungan hidup perusahaan, maka sebaiknya perlu dilakukan pengendalian terhadap biaya-biaya yang akan dikeluarkan dan mengurangi biaya-biaya yang tidak efektif dalam kegiatannya. Oleh karena itu, perusahaan perlu menerapkan akuntanbilitas guna menunjang pengendalian biaya. Semakin baik penerapan akuntanbilitas pada perusahaan maka akan semakin baik pula pengendalian biaya, sedangkan pengendalian biaya yang baik akan memudahkan penerapan akuntanbilitas dalam perusahaan sehingga tujuan perusahaan dapat dicapai.

Akuntansi pertanggungjawaban adalah suatu sistem akuntansi yang disusun sedemikian rupa sehingga pengumpulan serta pelaporan aset, biaya, dan pendapatan dilakukan sesuai dengan bidang akuntanbilitas di dalam sebuah perusahaan. Tujuannya agar ditunjuk orang atau kelompok orang yang bertanggung jawab atas penyimpangan aset, biaya, dan pendapatan yang dianggarkan (Mulyadi, 2005: 98).

Dengan adanya akuntanbilitas, pimpinan dapat mendelegasikan wewenang dan tanggung jawab ke tingkat pimpinan di bawahnya dengan lebih efisien tanpa memantau secara langsung seluruh kegiatan perusahaan. Akuntansi pertanggungjawaban juga perlu dievaluasi agar berlangsung dengan baik sehingga manajemen dapat dengan mudah menghubungkan biaya yang timbul dengan manajer pusat akuntanbilitasyang bertanggung jawab. Penerapan akuntanbilitas yang memadai mampu mendorong perusahaan guna mencapai tujuan perusahaan.

\section{Landasan Teori}

\section{Konsep dan pengertian akuntabilitas}

Menurut Taliziduhu Ndraha (2002 : 59, konsep akuntabilitas berawal dari konsep pertanggungjawaban, konsep pertanggungjawaban sendiri dapat dijelasakan dari adanya wewenang. Wewenang di sini berarti kekuasaan yang sah.

Sedangkan Menurut Weber (2001 : 129) ada tiga macam tipe ideal wewenang, pertama wewenang tradisional kedua wewenang karismatik dan ketiga wewenang legal rational. Yang ketigalah ini yang menjadi basis wewenang pemerintah. Dalam perkembanganya, muncul konsep baru tentang wewenang yang dikembangkan oleh Chester I. Barnard, yang bermuara pada prinsip bahwa penggunaan wewenang harus dapat dipertanggungjawabkan.

Darwin sebagaimana dikutip Joko Widodo (2004 : 221), membedakan konsep pertanggungjawaban menjadi tiga .Pertama, akuntabilitas (accountability), kedua, responsibilitas (responsibility) dan ketiga responsivitas (responsiveness).Sebelum menjelaskan tentang pertanggungajawaban sebagai akuntabilitas (accountability), di sini akan dijelaskan lebih dahulu pertanggungjawaban sebagai responsibilitas (responsibility) dan sebagai responsivitas (responsiveness). Responsibilitas (responsibility) merupakan konsep yang berkenaan dengan standar profesional dan kompetensi teknis yang dimiliki administrator 
(birokrasi publik) dalam menjalankan tugasnya. Administrasi negara dinilai responsibel apabila pelakunya memiliki standard profesionalisme atau kompetensi teknis yang tinggi. Sedangkan konsep responsivitas (responsiveness) merupakan pertanggungjawaban dari sisi yang menerima pelayanan (masyarakat). Seberapa jauh mereka melihat administrasi Negara (birokrasi publik) bersikap tanggap (responsive) yang lebih tinggi terhadap apa yang menjadi permasalahan, kebutuhan, keluhan dan aspirasi mereka. Pertanggungjawaban sebagai akuntabilitas (accountability) merupakan suatu istilah yang pada awalnya diterapkan untuk mengukur apakah dana publik telah digunakan secara tepat untuk tujuan di mana dana publik tadi ditetapkan dan tidak digunakan secara ilegal.

Dalam Taliziduhu Ndraha, Op.Cit., , hal.85 perkembanganya akuntabilitas digunakan juga bagi pemerintah untuk melihat akuntabilitas efisiensi ekonomi program. Usaha - usaha tadi berusaha untuk mencari dan menemukan apakah ada penyimpangan staf atau tidak, tidak efisien apa tidak prosedur yang tidak diperlukan. Akuntabilitas menunjuk pada pada institusi tentang "cheks and balance" dalam sistem administrasi. Mohamad Mahsun membedakan akuntabilitas dan responsibilitas, menururtnya keduanya merupakan hal yang saling berhubungan tetapi akuntabilitas lebih baik dan berbeda dengan akuntabilitas. Akuntabilitas didasarkan pada catatan/laporan tertulis sedangkan responsibilitas didasarkan atas kebijaksanaan. Akuntabilitas merupakan sifat umum dari hubungan otoritasi asimetrik misalnya yang diawasai dengan yang mengawasi, agen dengan prinsipal atau antara yang mewakil dengan yang diwakili. Dari segi fokus dan cakupanya, responsibility lebih bersifat internal sedangkan akuntabilitas lebih bersifat eksternal.

Mohamad Mahsun(2000 : 98) juga membedakan akuntabilitas dalam arti sempit dan arti luas, akuntabilitas dalam pengertian yang sempit dapat dipahami sebagai bentuk pertanggungjawban yang mengacu pada siapa organisasi (atau pekerja individu) bertangungjawab dan untuk apa organisasi bertanggngjawab. Sedang pengertian akuntabilitas dalam arti luas dapat dipahami sebagai kewajiban pihak pemegang amanah (agen) untuk meberikan pertanggungjawaban, menyajikan, melaporkan dan mengungkapkan segala aktivitas dan kegiatan yang menjadi tanggungjawabnya kepada pihak pemberi Joko Widodo, Op.Cit., hal 148.

97 LAN BPKP, Op.Cit hal. 4398 Miriam Budiarjo, (1998 : 78) Menggapai Kedaulatan Rakyat, ditetapkan melalui media pertanggungjawaban yang dilaksanakan secara periodik. Lembaga Administrasi Negara menyimpulkan akuntabilitas sebagai kewajiban seseorang atau unit organisasi untuk mempertanggungjawabkan pengelolaan dan pengendalaian sumberdaya dan pelaksanaan kebijakan yang dipercayakan kepadanya dalam rangka pencapaian tujuan yang telah ditetapkan melalui pertanggungjawaban secara periodik. Akuntabilitas dibedakan dalam beberapa macam atau tipe, Jabra \& Dwidevi sebagaiman dijelaskan oleh Sadu Wasistiono mengemukakan adanya lima perspektif akuntabilitas yaitu ;(2001:101)

a. Akuntabilitas administ atif/organisasi adalah pertanggungajwaban antara pejabat yang berwenang dengan unit bawahanya dalam hubungan hierarki yang jelas.

b. Akuntabilitas legal, akuntabilitas jenis ini merujuk pada domain publik dikaitkan dengan proses legislatif dan ydikatif. Bentuknya dapat berupa eninjauan kembali kebijakan yang telah diambil oleh pejabat publik maupun pembatalan suatu peraturan oleh institusi yudikatif. Ukuran akuntabilitas legal adalah peraturan perundang undangan yang berlaku

c. Akuntabilitas politik,

Sedarmayanti, (1999 : 21) Good Governance (Kepemerintahan Yang Baik), Membangun Sistem Manajemen Kinerja Guna Meningkatkan Produktivitas menuju Good Governance Op.Cit, hal. 100 LAN BPKP, Op.Cit hal 23101 Sadu Wasistiono, O.Cit.hal. Dalam tipe ini terkait dengan adanya kewenangan pemegang kekuasaan politik untuk mengatur, menetapkan prioritas dan pendistribusian sumber - sumber dab menjamain adanya kepatuhan melaksanakan tanggungjawab administrasi dan legal . Akuntabilitas ini memusatkan pada tekanan demokratik yang dinyatakan oleh administrasi public

d. Akuntabilitas profesional 
Hal ini berkaitan dengan pelaksnaan kinerja dan tindakan berdasarkan tolak ukur yang ditetapkan oleh orang profesi yang sejenis. Akuntabilitas ini lebih menekankan pada aspek kualitas kinerja dan tindakan.

e. Akuntabilitas moral.

Akunatabilitas ini berkaitan dengan tata nilai yang berlaku di kalagan masyarakat. Hal ini lebih banyak berbicara tentang baik atau buruknya suatu kinerja atau tindakan yang dilakukan oleh seseorang/badan hukum/pimpinan kolektif berdasarkan ukuran tata nilai yang berlaku setempat.

\section{Pengertian Anggaran.}

Anggaran merupakan kebutuhan yang sangat penting bagi setiap perusahaan, baik perusahaan yang bertujuan mencari laba maupun bertujuan non laba termasuk perusahaan jasa, perusahaan dagang dan perusahaan industri. Sebelum perusahaan beroperasi, perlu adanya rencana berupa anggaran, sehingga jelas misi dan target yang akan dicapai pada periode berikutnya. Bagi pimpinan perusahaan, anggaran merupakan sarana untuk keperluan rencana, koordinasi, pengawasan dan pengendalian. Untuk lebih memahami pengertian anggaran maka peneliti akan mengemukakan beberapa pendapat ahli tentang anggaran sebagai berikut:

Menurut Garrison, Norren and Brewer (2007:4), “Anggaran adalah rencana terperinci tentang perolehan dan penggunaan sumber daya keuangan dan sumber daya lainnya selama suatu periode waktu tertentu". Menurut M. Nafarin (2004:12), Anggaran merupakan rencan tertulis mengenai kegiatan suatu organisasi yang dinyatakan secara kuantitif dan umumnya dalam satuan uang untuk jangka waktu tertentu". Menurut Herawati dan Sunarto (2004:2)," Anggaran merupakan suatu rencana yang disusun secara sistematis dalam bentuk angka dan dinyatakan dalam unit moneter yang meliputi seluruh kegiatan perusahaan untuk jangka waktu tertentu dimasa yang akan datang".dari pendapat di atas, anggaran memiliki beberapa ciri antara lain rencana, seluruh kegiatan organisasi, dinyatakan dalam moneter, dan jangka waktu tertentu dimasa yang akan datang.

1. Rencana

Anggaran merupakan suatu rencana yang menggambarkan mengenai kegiatan perusahaan di masa yang akan datang.

2. Meliputi seluruh kegiatan

Anggaran akan dijadikan sebagai pendoman kerja dan juga sebagai sebagai alat kerja serta alat pengendalian, maka anggaran harus dapat mencakup semua kegiatan yang akan dilaksanakan oleh semua bagian yang ada di perusahaan. Apabila ada sebagian dari kegiatan perusahaan yang tidak mencakup dalam anggaran, berarti ada sebagian kegiatan yang tidak mempunyai pendoman atau arah.

3. Dinyatakan dalam satuan moneter

Unit moneter ini sangat dibutuhkan, mengingat bahwa setiap unit masing-masing berbeda seperti misalnya bahan baku menggunakan satuan berat (kg), satuan panjang $(\mathrm{m})$, satuan isi (l), tenaga kerja menggunakan satuan kerja ( misalnya harian ). Dengan unit moneter dapatlah diseragamkan semua satuan yang berbeda tersebut, sehingga perbedaan antara yang di rencanakan dengan yang direalisasikan memungkinkan untuk dijumlahkan, diperbandingkan serta dianalisa lebih lanjut.

4. Jangka waktu tertentu dimasa yang akan datang

Anggaran harus menunjukan secara jelas jangka waktu berlakunya angka-angka tersebut, agar dapat mempermudah penilaian pencapaian apa yang telah memungkinkan untuk dicapai, sesuai dengan waktu yang telah ditetapkan.

\section{Biaya Terkendali dan Biaya Tidak Terkendali}

Tanggung jawab yang diminta tiap departemen terhadap manajer pusat pertanggungjawaban adalah tanggung jawab atas biaya yang dapat mereka kendalikan secara langsung. Dengan demikian, manajer tiap pusat pertanggungjawaban tersebut dapat 
mengidentifikasi pendapatan dan biaya yang berada di bawah pengawasannya (controllable) dan yang tidak berada di bawah pengawasannya (uncontrollable). Hanya biaya dan pendapatan yang terkendali saja yang menjadi tanggung jawab tiap manajer pusat pertanggungjawaban (Putri,2005).

Definisi biaya terkendali menurut Daljono (2009:21) adalah :

"Biaya di mana manajer dapat mempengaruhi ada tidaknya dan besar kecilnya biaya tersebut. Apabila seorang manajer tidak dapat mempengaruhi suatu biaya melalui kebijakannya, maka biaya tersebut merupakan biaya tak terkendali bagi manajer tersebut." Semua biaya atau semua kegiatan yang menimbulkan biaya harus mendapat otorisasi dari orang-orang yang bertanggung jawab pada kegiatan tersebut. Oleh karena itu, semua biaya dapat dikendalikan pada tingkat manajemen tertentu. Jika suatu biaya tidak dapat dikendalikan pada tingkat manajemen tertentu, maka biaya tersebut harus dapat dikendalikan oleh tingkat manajemen yang lebih tinggi.

Berdasarkan konsep pengendalian biaya, setiap pos biaya pada suatu departemen atas unit organisasi harus diklasifikasikan dan ditentukan secara jelas sebagai biaya terkendali dan biaya tak terkendali pada setiap pusat pertanggungjawaban tertentu. Penentuan secara tegas ini sangat penting terutama dalam pengendalian biaya untuk laporan pelaksanaan, yang di dalamnya membandingkan antara realisasi dengan yang dianggarkan. Laporan tersebut merupakan tolok ukur keberhasilan pelaksanaan kerja setiap pusat pertanggungjawaban dan manajer yang membawahinya.

Untuk memisahkan biaya ke dalam biaya terkendali dan tidak terkendali pada kenyataannya seringkali ditemui kesulitan. Hanya sedikit biaya yang terjadinya menjadi tanggung jawab seseorang. Pedoman untuk menetapkan apakah suatu biaya dapat dibebankan sebagai tanggung jawab seorang manajer pusat pertanggungjawaban menurut Mulyadi (1997:164) adalah sebagai berikut:

1. Jika seorang manajer memiliki wewenang, baik dalam perolehan maupun penggunaan jasa, ia harus dibebani dengan biaya jasa tersebut. Seorang manajer jelas dapat mempengaruhi jumlah suatu biaya jika ia memiliki wewenang dalam memperoleh dan menggunakan jasa.

2. Jika seorang manajer dapat secara signifikan mempengaruhi jumlah biaya tertentu melalui tindakannya sendiri, ia dapat dibebani dengan biaya tersebut.

3. Seorang manajer mungkin tidak mempunyai wewenang dalam memutuskan perolehan barang atau jasa, baik harga maupun jumlahnya, namun dapat secara signifikan mempengaruhi jumlah pemakaiannya.

4. Meskipun seorang manajer tidak dapat secara signifikan mempengaruhi jumlah biaya tertentu melalui tindakan langsungnya sendiri, ia dapat juga dibebani biaya tersebut, jika manajemen puncak menghendaki agar ia menaruh perhatian, sehingga ia dapat membantu manajer lain yang bertanggung jawab untuk mempengaruhi biaya tersebut.

Sedangkan menurut Mulyadi (1997:165) juga mengemukakan bahwa biaya tidak terkendalikan dapat diubah menjadi biaya terkendalikan melalui dua cara yang saling berkaitan:

1. Mengubah dasar pembebanan dari alokasi ke pembebanan langsung.

Biaya yang dialokasikan kepada suatu pusat pertanggungjawaban dengan dasar yang sembarang, tidak dapat dimintakan pertanggungjawaban kepada manajer pusat pertanggungjawaban yang bersangkutan, sehingga biaya tersebut merupakan biaya tidak terkendalikan bagi manajer tersebut. Untuk mengubah menjadi biaya terkendalikan, biaya tersebut harus dibebankan sedemikian rupa kepada pusat pertanggungjawaban tertentu, sehingga biaya tersebut dapat dipengaruhi secara signifikan oleh manajer pusat pertanggungjawaban yang bersangkutan.

2. Mengubah letak tanggung jawab pengambilan keputusan.

Pengubahan biaya tidak terkendalikan menjadi biaya terkendalikan dapat pula dilakukan dengan cara mendelegasikan wewenang untuk pengambilan keputusan dari manajemen puncak kepada manajer pusat pertanggungjawaban yang bersangkutan. Dengan demikian, manajer pusat pertanggungjawaban yang sebelumnya tidak mempunyai wewenang untuk 
mempengaruhi biaya tertentu, dengan diterimanya wewenang dari manajemen puncak, akan dalam posisi dapat mempengaruhi biaya tersebut secara signifikan. Dalam sistem akuntansi pertanggungjawaban, semua biaya yang terkendalikan oleh manajer tingkat bawah, dipandang juga terkendalikan oleh manajer pusat pertanggungjawaban yang membawahinya.

\section{Efisiensi Biaya}

Definisi biaya menurut Daljono (2009:13) adalah: "Biaya merupakan suatu pengorbanan sumber ekonomi yang diukur dalam satuan uang, untuk mendapatkan barang atau jasa yang diharapkan akan memberikan keuntungan/manfaat pada saat ini atau masa yang akan datang."

Sedangkan Hansen dan Mowen (2009:47) mendefinisikan biaya sebagai berikut: "Biaya adalah kas atau nilai setara kas yang dikorbankan untuk mendapatkan barang atau jasa yang diharapkan memberi manfaat saat ini atau di masa depan bagi organisasi."

Dari beberapa pengertian di atas dapat disimpulkan bahwa biaya adalah suatu bentuk pengorbanan yang dapat diukur dengan satuan uang atas barang atau jasa untuk suatu tujuan tertentu.

\section{Pengertian Efektivitas.}

Efektivitas adalah hubungan antara output dan tujuan, dimana efektivitas diukur berdasarkan seberapa jauh tingkat output, kebijakan, dan prosedur organisasi mencapai tujuan yang telah ditetapkan. Secara sederhana, efektivitas merupakan perbandingan outcome dengan output. Efektivitas menunjukkan kesuksesan atau kegagalan dalam pencapaian tujuan (Indra Bastian, 2006 : 77). Ukuran efektivitas merupakan refleksi output.

Kemudian menurut (Devas,dkk, 2002: 279-280) Efektivitas adalah hasil guna kegiatan dalam mengurus keuangan harus sedemikian rupa sehingga memungkinkan program dapat direncanakan dan dilaksanakan untuk mencapai tujuan dengan biaya serendah-rendahnya dan dalam waktu yang secepat-cepatnya. Faktor penentu efisiensi dan efektivitas sebagai berikut:

1. Faktor sumber daya manusia seperti tenaga kerja, kemampuan kerja, maupun sumber daya fisik seperti perlatan kerja, tempat bekerja serta dana keuangan.

2. Faktor struktur organisasi yaitu susunan yang stabil dari jabatan-jabatan baik itu struktural maupun fungsional.

3. Faktor teknologi pelaksanaan pekerjaan.

4. Faktor dukungan kepada aparatur dan pelaksanaannya baik pimpinan maupun masyarakat.

5. Faktor pimpinan dalam arti kemampuan untuk mengkombinasikan keempat faktor tersebut ke dalam suatu usaha yang berdaya guna dan hasil guna untuk mencapai sasaran yang dimaksud.

Kemudian Indra Bastian (2006 : 77) menyatakan bahwa Tolak ukur dalam anggaran belanja suatu organisasi, baik organisasi yang berorientasi laba (swasta) maupun organisasi nonprofit (sektor publik) adalah Value For Money yang meliputi penilaian efisiensi, efektivitas, dan ekonomi. Dimana pengertian dari masing-masing elemen tersebut adalah :

1. Efisiensi adalah hubungan antara input dan output dimana barang dan jasa yang dibeli oleh organisasi digunakan untuk mencapai output tertentu. Atau dengan kata lain efisiensi merupakan perbandingan output/input yang dikaitkan dengan standar kinerja atau target yang telah ditetapkan (Indra Bastian, 2006 : 77). Efisiensi merupakan hal terpenting di antara ketiga hal tersebut. Suatu organisasi dirasa semakin efisien apabila rasio efisiensi cenderung di atas satu. Semakin besar angkanya, semakin tinggi tingkat efisiensinya. Secara absolute, rasio ini tidak menunjukkan posisi keuangan dan kinerja perusahaan. Namun, berbagai program di dua perusahaan dalam industri yang sama, dapat diperbandingkan tingkat efisiensinya. Apabila rasionya lebih besar dari satu dan dibandingkan dengan hasil rasio program yang sama di perusahaan lain, maka program tersebut bisa disebut lebih efisien (Indra Bastian 2006 : 208). 
2. Efektivitas adalah hubungan antara output dan tujuan, dimana efektivitas diukur berdasarkan seberapa jauh tingkat output, kebijakan, dan prosedur organisasi mencapai tujuan yang telah ditetapkan. Secara sederhana, efektivitas merupakan perbandingan outcome dengan output. Efektivitas menunjukkan kesuksesan atau kegagalan dalam pencapaian tujuan (Indra Bastian, 2006 : 77). Ukuran efektivitas merupakan refleksi output. Jika suatu organisasi bertujuan membangun suatu rumah sakit dengan 250 tempat tidur, 4 unit operasi, sebuah departemen kecelakaan dan darurat, serta departemen pasien luar dan semua target tersebut tercapai, maka mekanisme kerja organisasi tersebut efektif. Apabila hanya 150 tempat tidur yang terbangun, maka organisasi tersebut tidak bekerja efektif. Jadi tujuan tersebut harus spesifik, detail, dan terukur. Dalam rangka mencapai tujuan, organisasi sektor publik sering kali tidak memperhatikan biaya yang dikeluarkan. Hal seperti ini bisa terjadi apabila efisiensi biaya bukan merupakan bagian dari indikator hasil (Indra Bastian 2006 : 208).

3. Ekonomis adalah hubungan antara pasar dan input dimana barang dan jasa dibeli pada kualitas yang diinginkan pada harga terbaik yang dimungkinkan. Ekonomi terkait dengan sejauh mana organisasi sektor publik dapat meminimalisir input resources yang digunakan yaitu dengan menghindari pengeluaran yang boros dan tidak produktif (Indra Bastian 2006 : 77). Indikator ekonomi merupakan indikator tentang penggunaan input. pertanyaan yang diajukan adalah "apakah organisasi telah mengeluarkan biaya secara ekonomis?" (Indra Bastian 2006 : 208).

Dapat disimpulkan bahwa tiga indikator prestasi organisasi sektor publik akan dirinci sebagai berikut : ekonomi itu mengenai input, efisien tentang input dan output, dan efektifitas berhubungan dengan output dan outcome.

\section{Kerangka Analisis}

\begin{tabular}{|c|c|}
\hline Akuntanbilitas & Efisiensi dan Efektivitas \\
\hline $\begin{array}{l}\text { 1. Identifikasi Pusat PertanggungJawaban } \\
\text { 2. Ukuran Kerja } \\
\text { 3. Evaluasi Kerja }\end{array}$ & $\begin{array}{ll}\text { 1. } & \text { Prestasi } \\
\text { 2. } & \text { Varians } \\
\text { 3. } & \text { Rupiah }\end{array}$ \\
\hline
\end{tabular}

Gambar 1. Kerangka Analisis

\section{HASIL DAN PEMBAHASAN}

\section{Syarat Akuntanbility}

\section{a. Struktur Organisasi dan Pendelegasian Wewenang}

Struktur organisasi PT. Pelindo cabang Pulau Baai Bengkulu secara jelas telah menggambarkan jenjang wewenang, tanggung jawab, tugas dan kewajiban setiap tingkatan manajemen dengan baik. Perusahaan juga telah merumuskan dengan jelas fungsi-fungsi pokok, tugas dan tanggung jawab unit kerja. Berikut ini adalah susunan organisasi dan tata kerja organisasi di PT. Pelindo cabang Pulau Baai Bengkulu Susunan Organisasi Kantor PT. Pelindo cabang Pulau Baai Bengkulu Organisasi Kantor Cabang dipimpin oleh seorang General Manager yang dalam kedudukannya sebagai unit kerja pelaksana Kantor Pusat dibentuk berdasarkan lokasi pengusahaan. perusahaan dan dibedakan klasifikasinya berdasarkan bobot pengusahaan Kantor Cabang. Organisasi kantor cabang Makasar terdiri atas beberapa dinas sebagai berikut:

a) Dinas Usaha, membawahi unit kerja:

(1) Seksi Pemasaran dan Pengembangan Usaha;

(2) Seksi Pelayanan Kapal.

b) Dinas Armada, membawahi unit kerja:

(1) Seksi Nautika;

(2) Seksi Teknika.

c) Dinas Administrasi, membawahi unit kerja: 
(1) Seksi Akuntansi;

(2) Seksi Perbendaharaan;

(3) Seksi Sumber Daya Manusia dan Umum.

b. Tata Kerja Kantor Cabang

Kantor cabang sebagai unit kerja pelaksana kantor pusat dalam penyelenggaraan pelayanan jasa-jasa perusahaan, berfungsi dalam penyusunan rencana kerja, pengendalian, pengawasan dan pelaporan operasional dari kebijakan, strategi dan prosedur umum pengusahaan jasa-jasa perusahaan yang ditetapkan oleh Direksi perusahaan sesuai dengan ketentuan yang berlaku agar tercapai kinerja usaha yang tinggi, pelayanan jasa-jasa perusahaan yang berkualitas prima dan memuaskan pengguna jasa-jasa perusahaan secara optimal.

Dalam rangka memenuhi fungsi-fungsi tersebut, kantor cabang perusahaan mempunyai tugas-tugas pokok sebagai berikut:

1) Menyiapkan rencana kerja jangka pendek dan program kerja perusahaan pada tingkatan kantor cabang.

2) Menyiapkan pengaturan kebijaksanaan operasional berskala kantor cabang dalam penyelenggaraan pengelolaan perusahaan pada wilayah kerjanya.

3) Mengkoordinir, mengorganisasikan, mengendalikan dan mengawasi penyelenggaraan kegiatan operasional pengelolaan unit kerja perusahaan di wilayah kerja kantor cabang perusahaan.

4) Menyiapkan laporan berkala hasil pengelolaan kegiatan operasional penyelenggaraan jasajasa perusahaan dari unit kerja atau fungsi-fungsi di wilayah kerja kantor cabang sesuai dengan ketentuan yang berlaku.

_ General Manager

Bertanggung jawab kepada Direktur Utama untuk menyiapkan kerja dan program kerja perusahaan pada tingkatan kantor cabang.

- Dinas Usaha

Menyelenggarakan kegiatan perencanaan, pengkoordinasian, pengawasan dan pembuatan laporan bidang pemasaran dan penjualan jasa sesuai dengan ketentuan yang berlaku agar dicapai kinerja pangsa pasar (market share), volume penjualan, pendapatan perusahaan, produksi, kualitas pelayananjasa dan kepuasan pengguna jasa perusahaan di darat yang optimal dengan pembagian fungsi unit kerja seksi sebagai berikut:

1) Seksi pemasaran dan penjualan jasa

Melaksanakan kegiatan pemasaran dan penjualan jasa-jasa perusahaan sesuai dengan ketentuan yang berlaku agar dicapaikinerja pangsa pasar (market share), volume penjualan dan pendapatan perusahaan yang optimal;

2) Seksi pelayanan jasa

Melaksanakan kegiatan pelayanan jasa-jasa perusahaan sesuai dengan ketentuan yang berlaku agar dicapai kinerja produksi, kualitas pelayanan jasa dan kepuasan pengguna jasa perusahaan di darat (pre/post on board service) yang optimal.

- Dinas Armada

Menyelenggarakan kegiatan perencanaan, pengkoordinasian, pengawasan dan pembuatan laporan bidang pemeliharaan, perawatan dan perbaikan kapal sebagai alat produksi usaha jasa angkutan laut dan peralatan usaha jasa penunjang perusahaan sesuai dengan ketentuan yang berlaku agar dicapai laik laut (sea worthiness) dan kesiapan pakai kapal sebagai alat produksi yang optimal, efektif dan efisien dengan pembagian fungsi unit kerja seksi sebagai berikut:

1) Seksi nautika

Melaksanakan kegiatan pemeliharaan dan sertifikasi kapal, penyiapan pakai fasilitas dan peralatan telekomunikasi, elektronika, navigasi kapal, perlengkapan deck kapal, pelayanan dan perbekalan kapal sesuai dengan ketentuan yang berlaku agar dicapai kesiapan pakai (serviceability performance) dan kelaikan laut (sea worthiness) fasilitas nautika kapal serta 
kepuasan pengguna jasa (customer satisfaction) atas pelayanan penumpang di kapal (pre/post on board service) yang optimal;

2) Seksi teknika

Melaksankan kegiatan perencanaan dan analisis biaya penyiapan pakai kapal, penyediaan perbekalan teknik armada kapal sesuai dengan ketentuan yang berlaku agar dicapai tertib program pemeliharaan armada kapal, efektivitas dan efisiensi biaya penyiapan pakai, kelaikan laut (sea worthiness) serta penyediaan perbekalan teknik armada kapal perusahaan yang optimal.

_ Dinas administrasi

Menyelenggarakan kegiatan perencanaan, pengkoordinasian, pengawasan dan pembuatan laporan bidang anggaran, perbendaharaan, akuntansi, administrasi personalia, administrasi dan layanan umum kerumahtanggaan kantor serta pengamanan dan pengelolaan aset umum perusahaan agar dicapai kinerja pengelolaan akuntansi, keuangan, produktivitas SDM, ketertiban dan kelancaran administratif penyelenggaraan kantor yang optimal dengan pilahan fungsi unit kerja seksi sebagai berikut:

1) Seksi akuntansi

Melaksanakan kegiatan akuntansi keuangan, perpajakan, akuntansi manajemen dan anggaran perusahaan sesuai dengan ketentuan yang berlaku agar dicapai kinerja pencatatan akuntansi, pelaporan keuangan, perpajakan dan penganggaran perusahaan yang optimal;

2) Seksi keuangan

Melaksanakan kegiatan pengelolaan kas, hutang dan piutang serta program kemitraan dan bina lingkungan sesuai dengan ketentuan yang berlaku agar dicapai kinerja pengelolaankeuangan perusahaan yang optimal;

3) Seksi sumber daya manusia dan umum

Melaksanakan kegiatan pengelolaan administrasi personalia, pengembangan SDM, organisasi, adminstrasi perkantoran, layanan umum kerumahtanggaan kantor, pengamanan dan pengelolaan asset umum perusahaan sesuai dengan ketentuan yang berlaku agar dicapai produktivitas SDM, organisasi, administrasi dan layanan umum kerumahtanggaan kantor serta pengamanan dan pendayagunaan aset umum perusahaan yang optimal. Efektivitas organisasi untuk mewujudkan tujuan perusahaan sangat ditentukan oleh pengorganisasian sumber daya manusia di dalam memanfaatkan sumber daya lain melalui struktur organisasi. PT. Pelindo cabang Pulau Baai Bengkulu telah menyusun struktur organisasi dengan cukup baik. Hal ini dapat dilihat dari adanya penggambaran secara jelas pembagian wewenang dan tanggung jawab untuk tiap tingkatan manajemen dan hubungan kerja antar bagian-bagian dalam perusahaan. Dengan adanya struktur organisasi memungkinkan keberhasilan program perencanaan dan pengendalian yang ditetapkan perusahaan.

\section{c. Anggaran}

Anggaran dapat berfungsi sebagai alat perencanaan dan juga sebagai alat pengendalian. Suatu pengendalian biaya yang efektif ditunjang dengan adanya anggaran yang disusun sesuai dengan tingkat manajemen dalam organisasi. Dengan adanya susunan organisasi yang memiliki pembagian wewenang dan tanggung jawab yang jelas, perusahaan dapat menetapkan pihak yang bertanggung jawab jika terjadi penyimpangan dalam anggaran.

Proses penyusunan anggaran pada PT. Pelindo cabang Pulau Baai Bengkulu telah mengikutsertakan partisipasi manajer-manajer bagian. Hal ini dimaksudkan sebagai dasar perencanaan dan pengendalian keuangan perusahaan. Penyusunan anggaran ini biasanya dilakukan antara bulan Agustus sampai September dan paling lambat pada bulan Oktober.

Tujuan penyusunan anggaran pada PT. Pelindo cabang Pulau Baai Bengkulu adalah untuk mengetahui jumlah dana yang dibutuhkan masing-masing bagian perusahaan dalam membiayai seluruh kegiatan operasional yang akan dilaksanakan dan sebagai alat bantu bagi manajemen dalam mencegah terjadinya penyimpangan-penyimpangan terhadap penggunaan dana perusahaan. Dalam anggaran perusahaan juga ditetapkan siapa yang akan berperan 
dalam melaksanakan sebagian aktivitas pencapaian sasaran perusahaan dan sumber daya yang disediakan bagi pemegang peran tersebut untuk memungkinkannya melaksanakan tugas.

Penyusunan anggaran dilakukan dengan pendekatan Top Down dan Bottom Up. Pimpinan perusahaan terlebih dahulu menetapkan kebijakan yang memuat target operasional perusahaan periode yang akan datang sebagai dasar manajer untuk menyusun anggaran. Berdasarkan target operasional tersebut para manajer yang dibantu oleh para bawahannya mengajukan usulan anggaran yang diperlukan dalam melaksanakan aktivitas operasional. Dengan adanya partisipasi dari manajemen level bawah dalam proses penetapan anggaran, maka anggaran yang dibuat akan lebih baik karena disesuaikan dengan kondisi yang ada di lapangan sehingga diharapkan mampu meningkatkan pengendalian.

Anggaran yang dibuat oleh PT. Pelindo cabang Pulau Baai Bengkulu bersifat realistis dan tidak kaku. Anggaran yang telah ada dapat disesuaikan dengan situasi dan kondisi perusahaan yang mungkin berubah.

\section{d. Klasifikasi dan Kode Rekening}

Salah satu syarat penerapan akuntansi pertanggungjawaban adalah adanya klasifikasi dan kode rekening perusahaan. Berdasarkan hasil penelitian yang dilakukan, dapat dikatakan bahwa PT. Pelindo cabang Pulau Baai Bengkulu telah melakukan pengkodean rekening untuk setiap perkiraan dengan cukup memadai. Biaya-biaya yang terjadi dicatat untuk setiap tingkat manajemen, kemudian digolongkan dan diberi kode sesuai dengan tingkatan manajemen yang terdapat dalam struktur organisasi.

Klasifikasi dan kode rekening PT. Pelindo cabang Pulau Baai Bengkulu telah dikaitkan dengan pusat pertanggungjawaban yang ada di dalam perusahaan. Dengan demikian, kode rekening yang ada telah mencerminkan kewenangan pusat pertanggungjawaban dan mampu memberikan informasi mengenai tempat terjadinya biaya dan manajer yang bertanggung jawab atas terjadinya biaya tersebut. Pengklasifikasikan kode rekening di PT. Pelindo cabang Pulau Baai Bengkulu juga bertujuan untuk memudahkan penyusunan laporan keuangan.

Tabel 1. Golongan Dan Jenis Rekening Pada Masing-Masing Digit

\begin{tabular}{|c|l|}
\hline Golongan & \multicolumn{1}{c|}{ Rekening } \\
\hline 1 & Aktiva Lancar \\
3 & Aktiva Tetap \\
5 & Hutang \\
6 & Saldo Laba/Rugi tahun lalu \\
7 & Pendapatan Usaha \\
8 & Beban Usaha \\
9 & Beban lain-lain \\
\hline
\end{tabular}

Pada setiap penggolongan, dibagi lagi atau dirinci lagi untuk keperluan analisa dan pengawasan, dan dibuatkan rekening sub golongan yang lebih detail.

\section{e. Biaya Terkendali dan Biaya Tidak Terkendali}

Manajer memiliki wewenang sehingga dapat mengendalikan sesuatu yang berada di bawah kewenangannya. Oleh sebab itu, ada atau tidaknya wewenang manajer dapat mempengaruhi secara signifikan terhadap suatu biaya. Biaya dapat dikelompokkan menjadi dua golongan: (1) biaya terkendali dan (2) biaya tidak terkendali oleh manajer tersebut.

Biaya terkendali adalah biaya yang dapat dipengaruhi secara signifikan oleh manajer pusat pertanggungjawaban tertentu dalam jangka waktu tertentu. Suatu biaya tidak akan dapat dipengaruhi secara penuh oleh seorang manajer. Biaya terkendali hanya dapat dipengaruhi secara signifikan dengan wewenang yang dimiliki oleh manajer tertentu. Sedangkan biaya tidak terkendali merupakan biaya yang tidak dapat dipengaruhi secara signifikan oleh seorang manajer pusat pertanggungjawaban tertentu dalam jangka waktu tertentu.

Pemisahan antara biaya-biaya yang terkendali dengan yang tidak terkendali sangat penting untuk menetapkan pusat pertanggungjawaban yang bertanggung jawab atas realisasi 
dan penyimpangan dari suatu anggaran. Manajemen dapat mengetahui di mana biaya terjadi dan siapa yang harus bertanggung jawab atas realisasi dan penyimpangan pada anggaran biaya. Dengan mengetahui tempat biaya dan penanggungjawab biaya, manajemen akan lebih mudah mengendalikan biaya. Namun PT. Pelindo cabang Pulau Baai Bengkulu belum melakukan pemisahan biaya terkendali dan biaya tidak terkendali dengan cukup memadai, tidak ada pemisahan antar biaya terkendali dan biaya tidak terkendali yang dilakukan pada anggaran yang dibuat oleh PT. Pelni.

\section{f. Laporan Pertanggungjawaban}

Salah satu unsur penting dalam akuntansi pertanggungjawaban adalah laporan pertanggungjawaban kepada manajer yang bertanggung jawab. Laporan pertanggungjawaban berisi informasi yang berguna bagi pengambilan keputusan manajer. Laporan pertanggungjawaban biaya disajikan untuk memungkinkan setiap manajer melakukan pengelolaan biaya. Laporan ini berisi mengenai biaya-biaya yang dianggarkan, biaya yang sebenarnya dan selisihnya. Dengan demikian, manajer memiliki dasar untuk memantau pelaksanaan anggaran.

PT. Pelindo cabang Pulau Baai Bengkulu telah membuat laporan pertanggungjawaban berupa laporan realisasi anggaran triwulanan. Pertanggungjawaban tiap unit usaha, dilakukan oleh masingmasing kepala cabang yang nantinya akan melaporkan anggaran dan realisasi yang terjadi pada unit usaha tersebut ke kantor pusat. Laporan periodik triwulanan ini harus diserahkan kepada Komisaris / Dewan Pengawas dan Pemegang Saham untuk Persero atau Menteri Keuangan paling lambat 1 (satu) bulan setelah berakhirnya periode laporan. Periode laporan per triwulanan ini menunjukkan bahwa pemantauan kinerja dilakukan secara berkesinambungan terhadap unit kerja organisasi dalam mencapai sasaran yang telah ditetapkan.

\section{Tabel 2. Periode Laporan}

\begin{tabular}{|c|c|}
\hline Triwulanan & Periode Berakhir \\
\hline I & 31 Maret \\
\hline II & 30 Juni \\
\hline III & 30 September \\
\hline IV & 31 Desember \\
\hline
\end{tabular}

Laporan pertanggungjawaban kinerja usaha pada kantor PT. Pelindo cabang Pulau Baai Bengkulu periode triwulan-IV dan s/d semester II 2013 dapat dilihat bahwa :

- Realisasi penghasilan usaha perkapalan pada triwulan IV/2013 sebesar Rp 45.131.199.000,00 atau 145\% dari anggaran sejumlah Rp 31.096.597.000,00. Sampai dengan semester II/2013 tercapai sebesar Rp 155.014.210.000,00 atau 131\% dari anggaran sebesar Rp 117.946.371.000,00 apabila dibandingkan dengan tahun 2010 tercapai $141 \%$.

- Realisasi penghasilan usaha cabang pada triwulan IV/2013 sebesar Rp 2.592.636.000,00 atau 136\% dari anggaran sejumlah Rp 1.910.398.000,00. Sampai dengan semester II/2013 tercapai sebesar $\mathrm{Rp} 9.046 .514 .000,00$ atau $124 \%$ dari anggaran sebesar Rp 7.291.590.000,00 apabila dibandingkan dengan tahun 2012 tercapai 131\%.

- Realisasi biaya usaha cabang pada triwulan IV/2013 sebesar Rp 1.300.074.000,00 atau $210 \%$ dari anggaran sejumlah Rp 619.925.000,00. Sampai dengan semester II/2012 tercapai sebesar $\mathrm{Rp} 4.825 .430 .000,00$ atau $195 \%$ dari anggaran sebesar Rp 2.479.700.000,00 apabila dibandingkan dengan tahun 2012 tercapai 115\%.

- Realisasi laba usaha pada triwulan IV/2013 sebesar Rp 1.292.562.000,00 atau 100\% dari anggaran sejumlah Rp 1.290.473.000,00. Sampai dengan semester II/2013 tercapai sebesar Rp 4.221.084.000,00 atau 88\% dari anggaran sebesar $\mathrm{Rp}$ 4.811.890.000,00 apabila dibandingkan dengan tahun 2012 tercapai $156 \%$.

- Realisasi laba di luar usaha pada triwulan IV/2013 sebesar Rp 395.778.000,00 atau 732\% dari anggaran sejumlah Rp 54.103.000,00. Sampai dengan semester II/2011 tercapai 
sebesar Rp 1.185.727.000,00 atau 548\% dari anggaran sebesar Rp 216.411.000,00 apabila dibandingkan dengan tahun 2012 tercapai 153\%.

- Realisasi laba sebelum overhead pada triwulan IV/2013 sebesar Rp 1.688.340.000,00 atau $126 \%$ dari anggaran sejumlah Rp 1.344.576.000,00. Sampai dengan semester II/2013 tercapai sebesar Rp 5.406.811.000,00 atau 108\% dari anggaran sebesar Rp 5.028.301.000,00 apabila dibandingkan dengan tahun 2012 tercapai 155\%.

- Realisasi biaya overhead pada triwulan IV/2013 sebesar Rp 778.596.000,00 atau 88\% dari anggaran sejumlah Rp 885.769.000,00. Sampai dengan semester II/2013 tercapai sebesar Rp 2.751.681.000,00 atau 80\% dari anggaran sebesar Rp 3.460.840.000,00 apabila dibandingkan dengan tahun 2012 tercapai 99\%.

- Realisasi laba usaha cabang pada triwulan IV/2013 sebesar Rp 909.744.000,00 atau 198\% dari anggaran sejumlah Rp 458.807.000,00. Sampai dengan semester II/2011 tercapai sebesar Rp 2.655.130.000,00 atau 169\% dari anggaran sebesar Rp 1.567.461.000,00 apabila dibandingkan dengan tahun 2012 tercapai 369\%.

Berdasarkan keterangan di atas, dapat dikatakan bahwa laporan pertanggungjawaban di PT. Pelindo Cabang Pulau Baai Bengkulu telah cukup memadai. Pada kenyataannya kecil kemungkinan biaya yang sesungguhnya terjadi sama dengan biaya yang dianggarkan karena adanya situasi dan kondisi yang berubah-ubah dan terdapat beberapa kemungkinan yang tidak dapat diprediksi sebelumnya, seperti kenaikan harga BBM dan pencapaian load factor kapal penumpang yang masih bersaing dengan moda transportasi lain.

\section{Karakteristik Akuntanbility}

\section{a. Identifikasi Pusat Akuntanbility}

Suatu pusat akuntanbility dibentuk untuk membantu pencapaian tujuan suatu organisasi sebagai suatu keseluruhan. Dalam prakteknya, suatu pusat pertanggungjawaban diberi tanggung jawab berdasarkan spesialisasi dan bidang yang ditempatinya.

Struktur organisasi PT. Pelindo Cabang Pulau Baai Bengkulu telah membagi bagian kerja atas pusat-pusat pertanggungjawaban, yaitu pusat biaya, pusat pendapatan, pusat laba dan pusat investasi. Dalam penelitian ini pembahasan hanya dipusatkan terhadap pusat biaya, di mana PT. Pelindo Cabang Pulau Baai Bengkulu telah mengidentifikasikan pusat biaya sebagai berikut :

1). Dinas armada sebagai pusat biaya armada yang bertanggung jawab dalam menyelenggarakan kegiatan perencanaan, pengkoordinasian, pengawasan dan pembuatan laporan bidang pemeliharaan, perawatan dan perbaikan kapal sebagai alat produksi usaha jasa angkutan laut dan peralatan usaha jasa penunjang perusahaan.

2). Dinas administrasi sebagai pusat biaya administrasi yang bertanggung jawab dalam menyelenggarakan kegiatan perencanaan, pengkoordinasian, pengawasan dan pembuatan laporan bidang anggaran, perbendaharaan, akuntansi, administrasi personalia, administrasi dan layanan umum kerumahtanggaan kantor serta pengamanan dan pengelolaan aset umum perusahaan.

Dengan demikian dapatlah dikatakan bahwa struktur organisasi perusahaan telah memenuhi salah satu karakteristik akuntansi pertanggungjawaban yaitu adanya identifikasi pusat-pusat pertanggungjawaban.

\section{b. Standar Pengukuran Kinerja}

Anggaran dapat digunakan sebagai standar dalam menilai kinerja manajer pusat pertanggungjawaban. Penilaian kinerja manajer dilakukan berdasarkan perbandingan antara realisasi biaya dengan anggaran biaya yang terdapat pada laporan pertanggungjawaban.

\section{c. Pengukuran Kinerja Manajer}

Di PT. Pelindo Cabang Pulau Baai Bengkulu terdapat laporan pertanggungjawaban berupa laporan realisasi anggaran yang dapat dijadikan dasar yang memadai untuk mengukur kinerja manajer. Dengan adanya jenis laporan seperti itu, maka kinerja manajer dapat diukur oleh perusahaan. Laporan ini berisi mengenai biaya-biaya yang dianggarkan, biaya yang sebenarnya dan selisihnya. 


\section{d. Manajer secara Individual Diberikan Penghargaan atau Hukuman}

Dengan membandingkan antara realisasi biaya dengan anggaran biaya yang terdapat pada laporan pertanggungjawaban, maka akan diperoleh selisih atas biaya tersebut. Apabila terdapat selisih yang menguntungkan, maka manajer tersebut akan mendapat penghargaan atas prestasinya. Sedangkan jika terdapat penyimpangan yang tidak menguntungkan, maka manajer tersebut akan dimintai pertanggungjawaban atas kinerjanya. Jika manajer tersebut tidak dapat memberikan pertanggungjawaban, maka perusahaan akan memberikan hukuman. Pemberian penghargaan dan hukuman ini disesuaikan dengan Perjanjian Kerja Bersama (PKB) yang telah ditetapkan oleh PT. Pelindo cabang Pulau Baai Bengkulu Sebagai contoh, bonus 50\% gaji diberikan kepada para karyawan atas pencapaian kinerja kantor cabang yang dinilai baik. Sedangkan manajer akan diberikan kenaikan pangkat atas kinerjanya yang dinilai memuaskan.

\section{Kelayakan Pengendalian Biaya}

\section{a. Adanya pencatatan dan otorisasi untuk pengeluaran biaya}

PT. Pelindo Cabang Pulau Baai Bengkulu telah melaksanakan pencatatan dan otorisasi untuk pengeluaran biaya yang memadai, ini terlihat dari :

- Secara berkesinambungan mengadakan pemantauan atas sistem dan prosedur administrasi keuangan, meneliti dan menganalisa laporan keuangan, mengawasi dan mencatat biaya yang terjadi.

- Melakukan pengawasan dan verifikasi serta pemeriksaan formal laporan keuangan atas biaya dari kegiatan usaha perusahaan.

- Melakukan verifikasi atas semua bukti-bukti keabsahan pengeluaran sebelum dilakukan pembayaran.

b. Adanya analisis untuk penyimpangan yang terjadi.

Perusahaan menyusun anggaran dalam rangka pengendalian biaya. Biaya yang sesungguhnya dianalisis dengan cara membandingkan dengan anggaran sehingga dapat diketahui penyimpangan yang terjadi. Apabila terdapat penyimpangan yang tidak menguntungkan, maka perusahaan dapat segera menelusuri penyebabnya dan mengambil tindakan koreksi. PT Pelindo cabang Pulau Baai Bengkulu telah melakukan perhitunganperhitungan analisis laporan keuangan, baik untuk intern maupun kepentingan ekstern, anak perusahaan, usaha penunjang, usaha sampingan dan usaha-usaha lainnya. Hasil dari analisis tersebut dicantumkan dalam memori penjelasan laporan realisasi anggaran. Akan tetapi, perusahaan tidak melakukan penelusuran mendalam sehingga sulit untuk mengambil tindakan koreksi.

c. Adanya rekomendasi menanggapi penyimpangan materiil.

Dengan adanya penyimpangan yang tidak menguntungkan, sebaiknya dibuat rekomendasi guna menanggapi penyimpangan materiil. Namun, sejauh ini perusahaan belum melakukannya.

\section{Penerapan Akuntanbility Melalui Anggaran Sebagai Alat Pengendalian Biaya. \\ a. Akuntanbility}

Akuntanbility merupakan salah satu tipe informasi akuntansi manajemen. akuntanbility memfokuskan terhadap pembagian wewenang kepada manajer yang bertanggung jawab. akuntanbility berperan sebagai alat pengendalian biaya dengan menghubungkan biaya dengan bagian di mana biaya tersebut dikeluarkan atau diperoleh oleh manajer yang bertanggungjawab pada bagian tersebut. Pelaksanaan perencanaan dan pengendalian dalam suatu perusahaan memerlukan sistem akuntansi pertanggungjawaban. Setiap pusat akuntanbility selalu menetapkan target-target operasional dan anggaran. Dengan membandingkan realisasi dan dengan anggaran, seorang manajer pusat pertanggungjawaban dapat mengetahui apakah pengendalian biaya telah berja Melalui akuntanbility, biaya dikelompokkan dan dilaporkan untuk tiap tingkatan manajemen yang hanya dibebani dengan biaya-biaya yang berada di bawah pengendaliannya atau yang berada di bawah tanggung jawabnya. 
Dengan demikian, manajer dapat melakukan pengendalian dan pengawasan atas pengeluaran biaya. Selain itu, biaya juga harus dilaporkan dan dibandingkan dengan anggaran yang telah ditetapkan terlebih dahulu. Hal ini dapat membantu manajemen dalam melakukan pengendalian biaya dengan menganalisis penyimpangan yang terjadi. Laporan pertanggungjawaban dapat digunakan sebagai tolok ukur penilaian kinerja manajer pusat pertanggungjawaban dalam melaksanakan pengendalian biaya karena secara berkala manajemen puncak menerima laporan pertangungjawaban dari setiap tingkatan manajemen. Dengan demikian, akuntansi pertanggungjawaban mendorong manajer untuk mencapai tujuan pengendalian. Dengan membandingkan antara teori-teori yang telah ada dengan data-data yang didapat dari studi kasus maka dapat dikatakan bahwa penerapan akuntansi pertanggungjawaban pada PT. Pelindo Cabang Pulau Baai Bengkulu belum memadai. Suatu penerapan akuntansi pertanggungjawaban dapat dikatakan memadai jika telah memenuhi syarat dan karakteristik akuntansi pertanggungjawaban. Dalam pembahasan ini dapat dilihat bahwa perusahaan belum melakukan pemisahan biaya terkendali dan biaya tidak terkendali. Dengan tidak adanya pemisahan biaya terkendali dan tidak terkendali, maka perusahaan tidak dapat melakukan pengendalian biaya dengan baik. Anggaran yang telah ditetapkan perusahaan tidak dapat digunakan untuk mengukur kinerja manajer. Selain itu, laporan pertanggungjawaban juga tidak mencerminkan besarnya biaya yang menjadi tanggung jawab manajer. Manajer hanya dimintai pertanggungjawaban atas biaya-biaya yang dapat dikendalikannya saja.Sedangkan pengendalian biaya dapat dikatakan baik jika telah memenuhi kelayakan pengendalian biaya secara memadai dan efisien. Dalam hal ini PT. Pelindo cabang Pulau Baai Bengkulu belum dapat melakukan pengendalian biaya dengan baik karena tidak adanya pemisahan biaya terkendali dan biaya tidak terkendali sehingga sulit dilakukan analisis yang mendalam mengenai penyimpangan biaya yang terjadi.

Dalam penelitian ini anggaran digunakan sebagai informasi akuntansi pertanggungjawaban. Dengan menganalisis anggaran tersebut, dapat diketahui efisiensi dari pengendalian biaya yang telah dilakukan perusahaan. Realisasi biaya yang terjadi dibandingkan dengan anggaran yang telah ditetapkan sebelumnya di mana hasil analisis tersebut disajikan berupa persentase perbandingan. Dari analisis laporan realisasi anggaran triwulanan perusahaan, dapat dilihat bahwa pengendalian biaya pada PT. Pelindo cabang Pulau Baai Bengkulu belum efisien.

\section{b. Efisiensi Pengendalian Biaya}

Tolok ukur yang digunakan perusahaan untuk mengukur efisiensi dari pengendalian biaya adalah dengan membandingkan antara biaya usaha dengan biaya standar. Berikut ini adalah analisis biaya PT. Pelindo cabang Pulau Baai Bengkulu triwulan-IV tahun 2011.

- Realisasi biaya usaha cabang pada triwulan IV tahun 2013 sebesar Rp 1.300.074.000,00 atau $210 \%$ dari anggaran sejumlah $\mathrm{Rp} 619.925 .000,00$. Hal ini menunjukkan adanya selisih yang tidak menguntungkan yaitu sebesar Rp 680.149.000,00, realisasi biaya lebih dari $100 \%$ atau melebihi anggaran biaya usaha yang telah ditetapkan.

- Realisasi biaya pegawai pada triwulan IV tahun 2013 sebesar Rp 485.689.000,00 atau 83\% dari anggaran sejumlah Rp 586.284.000,00. Hal ini menunjukkan adanya selisih yang menguntungkan yaitu sebesar Rp 100.595.000,00, realisasi biaya kurang dari 100\% atau tidak melebihi anggaran biaya pegawai yang telah ditetapkan.

- Realisasi biaya barang dan jasa pada triwulan IV tahun 2013 sebesar Rp 290.663.000,00 atau $158 \%$ dari anggaran sejumlah $\mathrm{Rp} 183.700 .000,00$. Hal ini menunjukkan adanya selisih yang tidak menguntungkan yaitu sebesar Rp 106.963.000,00, realisasi biaya lebih dari $100 \%$ atau melebihi anggaran biaya barang dan jasa yang telah ditetapkan.

- Realisasi biaya penyusutan pada triwulan IV tahun 2013 sebesar Rp 59.744.000,00 atau $40 \%$ dari anggaran sejumlah $\mathrm{Rp}$ 150.285.000,00. Hal ini menunjukkan adanya selisih yang menguntungkan yaitu sebesar Rp 90.541.000,00, realisasi biaya kurang dari 100\% atau tidak melebihi anggaran biaya penyusutan yang telah ditetapkan.

- Realisasi lumpsum overhead SBN pada triwulan IV tahun 2013 sebesar Rp 57.500.000,00 atau $167 \%$ dari anggaran sejumlah Rp 34.500.000,00. Hal ini menunjukkan adanya 
selisih yang tidak menguntungkan yaitu sebesar Rp 23.000.000,00, realisasi biaya lebih dari $100 \%$ atau melebihi anggaran lumpsum overhead SBN yang telah ditetapkan.

Berdasarkan analisis di atas, maka dapat disimpulkan bahwa biaya yang terjadi pada PT Pelindo Cabang Pulau Baai Bengkulu belum efisien.

\section{c. Efektifitas Kerja Keuangan.}

Secara umum penyusunan Rencana Kerja dan Anggaran Perusahaan (RKAP) telah sesuai dengan pedoman/ketentuan yang berlaku dan kebijakan manajemen secara keseluruhan. Pengesahan RKAP tahun 2013 dilakukan melalui Rapat Umum Pemegang Saham tanggal 29 Desember 2012. Kebijakan manajemen tersebut telah dirumuskan secara realistis sesuai dengan kondisi yang ada dan prospek perkembangan perseroan.

Perbandingan antara realisasi tahun 2013 dengan RKAP dan realisasi tahun 2012 :

a. Pendapatan

Realisasi pendapatan tahun 2013 secara keseluruhan sebesar Rp1.755.347.589.427,00 atau mencapai 99,74\% dari anggarannya yaitu Rp1.759.916.659.000,00. Hampir semua jenis pendapatan mengalami peningkatan dari anggarannya kecuali pendapatan pelayanan jasa kapal, pengusahaan TBAL, pendapatan rupa-rupa usaha dan pendapatan luar usaha yang masing-masing mencapai 92,52\%, 68,17\%, 92,92\% dan 77,65\%. Bila dibandingkan dengan realisasi pendapatan tahun 2012, secara umum pendapatan tahun 2013 mengalami peningkatan rata-rata $113,44 \%$ kecuali untuk pendapatan pengusahaan TBAL dan pendapatan luar usaha. Realisasi pendapatan usaha tahun 2013 sebesar Rp1.549.795.033.015,00 atau mencapai 103,65\% dari anggarannya yaitu Rp1.495.189.926.000,00 dan 118,10\% bila dibandingkan dengan realisasi tahun 2013. Realisasi pendapatan luar usaha tahun 2013 sebesar Rp205.552.556.412,00 atau hanya mencapai 77,65\% bila dibandingkan dengan anggarannya yaitu Rp264.726.733.000,00. Bagian terbesar dari pendapatan di luar usaha adalah pendapatan selisih kurs, laba penjualan aktiva tetap/surat berharga dan pendapatan lain-lain yaitu masing-masing Rp114.755.429.855,00, Rp28.209.229.975,00 dan $\mathrm{Rp}$ 49.745.571.771,00. Secara rinci realisasi pendapatan tahun 2013 dibandingkan dengan anggaran dan realisasi tahun 2012.

\section{Kesimpulan}

1. Penerapan akuntanbility pada perusahaan belum memadai. Hal ini didukung oleh belum terpenuhinya indikator penerapan akuntanbility sebagai berikut:

a. Syarat-syarat akuntanbility yang terdiri dari:

1. Struktur organisasi dan pendelegasian wewenang

PT. Pelindo cabang Pulau Baai Bengkulu telah menyusun struktur organisasi dengan cukup baik. Hal ini dapat dilihat dari adanya penggambaran secara jelas pembagian wewenang dan tanggung jawab untuk tiap tingkatan manajemen dan hubungan kerja antar bagian-bagian dalam perusahaan. Dengan adanya struktur organisasi memungkinkan keberhasilan program perencanaan dan pengendalian yang ditetapkan perusahaan.

2. Anggaran yang disusun oleh setiap bagian

Berdasarkan penelitian yang dilakukan, setiap pusat pertanggungjawaban telah menyusun anggarannya masing-masing. Penyusunan anggaran pada PT. Pelindo bertujuan untuk mengetahui jumlah dana yang dibutuhkan masing-masing bagian perusahaan dalam membiayai seluruh kegiatan operasional yang akan dilaksanakan dan sebagai alat bantu bagi manajemen dalam mencegah terjadinya penyimpanganpenyimpangan terhadap penggunaan dana perusahaan

3. Pemisahan biaya terkendali dan biaya tidak terkendali PT. Pelindo Cabang Pulau Baai Bengkulu belum melakukan pemisahan biaya terkendali dan biaya tidak terkendali dengan cukup memadai, tidak ada pemisahan antara biaya terkendali dan biaya tidak terkendali yang dilakukan pada anggaran yang dibuat oleh PT. Pelindo

4. Pengklasifikasian kode rekening 
Klasifikasi kode rekening juga telah diterapkan oleh PT. Pelindo Cabang Pulau Baai Bengkulu dengan cukup memadai. Biaya-biaya yang terjadi dicatat untuk setiap tingkat manajemen, kemudian digolongkan dan diberi kode sesuai dengan tingkatan manajemen yang terdapat dalam struktur organisasi.

5. Laporan akuntanbility kepada manajer yang bertanggung jawab PT. Pelindo Cabang Pulau Baai Bengkulu telah membuat laporan akuntanbility berupa laporan realisasi anggaran. Pada laporan akuntanbility dapat dilihat berapa besarnya perbandingan antara anggaran dengan realisasinya, serta selisihnya. akuntanbility tiap unit usaha, dilakukan oleh masingmasing kepala cabang yang nantinya akan melaporkan anggaran dan realisasi yang terjadi pada unit usaha tersebut ke kantor pusat.

b. Karakteristik akuntanbility di PT. Pelindo Cabang Pulau Baai Bengkulu yang terdiri atas:

1. Identifikasi pusat akuntanbility.

Struktur organisasi PT. Pelindo Cabang Pulau Baai Bengkulu telah membagi bagian kerja atas pusat-pusat pertanggungjawaban.

2. Standar tolok ukur kinerja manajer

Di PT. Pelindo cabang Pulau Baai Bengkulu telah ditetapkan beberapa standar untuk menilai kinerja para manajernya. Untuk menilai kinerja manajer pusat akuntanbility, dilakukan perbandingan antara realisasi biaya dengan anggaran biaya yang terdapat pada laporan akuntanbility.

3. Pengukuran kinerja manajer pusat akuntanbility

Di PT. Pelindo cabang Pulau Baai Bengkulu terdapat laporan akuntanbility berupa laporan realisasi anggaran yang dapat digunakan untuk mengukur kinerja manajer.

Dengan adanya jenis laporan seperti itu, maka kinerja manajer dapat diukur oleh perusahaan.

4. Pemberian penghargaan/hukuman kepada manajer

Manajer secara individual diberi penghargaan atas prestasi yang dicapainya atau lamanya bekerja, dan manajer juga diberi hukuman atas penyimpangan yang dilakukannya. Pemberian penghargaan dan hukuman ini disesuaikan dengan Perjanjian Kerja Bersama (PKB) yang telah ditetapkan oleh PT. Pelindo cabang Pulau Baai Bengkulu

2. Pelaksanaan pengendalian biaya pada PT. Pelindo cabang Pulau Baai Bengkulu belum memadai, hal ini dapat dilihat dari:

- PT. Pelindo cabang Pulau Baai Bengkulu telah melaksanakan pencatatan dan otorisasi untuk pengeluaran biaya yang memadai.

- PT. Pelindo cabang Pulau Baai Bengkulu telah melakukan perhitungan analisis laporan keuangan, namun perusahaan tidak melakukan penelusuran mendalam sehingga sulit untuk mengambil tindakan koreksi.

- Perusahaan tidak membuat rekomendasi sehubungan dengan adanya penyimpangan materiil.

3. Akuntanbility berperan sebagai alat pengendalian biaya, hal ini dapat dilihat dari:

a. Akuntanbility berperan sebagai alat pengendalian biaya dengan menghubungkan biaya dengan bagian di mana biaya tersebut dikeluarkan atau diperoleh oleh manajer yang akuntanbility pada bagian tersebut.

b. Setiap pusat akuntanbility selalu menetapkan target-target operasional dan anggaran. Dengan membandingkan realisasi dan dengan anggaran, seorang manajer pusat akuntanbility dapat mengetahui apakah pengendalian biaya telah berjalan secara efektif dan telah menggunakan biaya secara efisien.

c. Laporan akuntanbility dapat digunakan sebagai tolok ukur penilaian kinerja manajer pusat akuntanbility dalam melaksanakan pengendalian biaya karena secara berkala manajemen puncak menerima laporan akuntanbility dari setiap tingkatan manajemen. Dengan demikian, akuntanbility mendorong manajer untuk mencapai tujuan pengendalian.

4. Pengelolaan anggaran dan target yang dicapai oleh pihak PT. Pelindo Cabang Pulau Baai Bengkulu selama tahun anggaran 2012-2013 dapat disimpulkan cukup efektif. 


\section{Saran}

1. Akuntanbility pada PT. Pelindo cabang Pulau Baai Bengkulu pada dasarmya belum diterapkan dan dilaksanakan dengan baik. Begitu juga dalam pelaksanaan pengendalian biaya, perusahaan belum melakukan pengendalian dengan cukup baik.

2. Masih ditemukan beberapa kelemahan dalam perusahaan. Oleh karena itu, penulis mencoba memberikan saran berdasarkan teori yang telah dipelajari selama perkuliahan mengenai penerapan akuntanbility yang berperan sebagai alat pengendalian biaya. Saran ini diharapkan dapat menjadi masukan bagi perusahaan, yaitu:

a. Dalam anggaran maupun laporan akuntanbility sebaiknya dilakukan pemisahan biaya-biaya yang dapat dikendalikan maupun yang tidak dapat dikendalikan oleh manajer karena hanya biaya yang dapat dikendalikan saja yang dapat dimintai pertanggungjawabannya.

b. Manajer sebaiknya melakukan analisis dan koreksi terhadap penyimpangan yang tidak menguntungkan kemudian mengajukan rekomendasi menanggapi penyimpangan materiil yang terjadi.

c. Untuk penelitian selanjutnya, diharapkan mampu menilai tingkat kesehatan kantor cabang dengan memasukkan aspek keuangan, aspek operasional, dan aspek dinamis sesuai dengan ketentuan dari kantor pusat. Aspek-aspek tersebut berisi indikatorindikator yang merupakan unsur kegiatan yang dianggap paling dominan dalam rangka menunjang keberhasilan operasi sesuai dengan visi dan misi perusahaan.

\section{DAFTAR PUSTAKA}

Adisaputro, G dan Y. Anggarini. 2007. Anggaran Bisnis : Analisis, Perencanaan,dan Pengendalian Laba. Yogyakarta : UPP STIM YKPN.

Anthony, R. N. dan V. Govindarajan. 2005. Sistem Pengendalian Manajemen Jilid 2.Jakarta: Salemba Empat.

Anthony, R. N. dan V. Govindarajan. 2009. Sistem Pengendalian Manajemen Jilid 1.Jakarta: Salemba Empat.

Ayuningtyas, S. 2006. Efisiensi dan Keefektivan Penerapan AkuntansiPertanggungjawaban sebagai Alat Pengendalian dan Evaluasi KinerjaManajemen. www.google.com

Chariri, A dan I. Ghozali. 2007. Teori Akuntansi. Semarang: Badan Penerbit Universitas Diponegoro.

Daljono. 2009. Akuntansi Biaya: Penentuan Harga Pokok dan Pengendalian.Semarang: Badan Penerbit Universitas Diponegoro.

Hafid, A. R. 2007. Peranan Anggaran Biaya Operasi dalam Menunjang Efektivitas Pengendalian Biaya Operasi. www.google.com

Hansen, D. R. dan M. M. Mowen. 2009. Akuntansi Manajerial. Jakarta: Salemba Empat.

J. Supranto (2001 : 15), Pengantar Metodologi Penelitian. LP3ES Jakarta

Mardiasmo. 2002. Akuntansi Sektor Publik. Yogyakarta: Penerbit Andi.

Mulyadi. 2005. Akuntansi Manajemen : Konsep, Manfaat, dan Rekayasa, Edisi ke-2.Yogyakarta : Bagian Penerbitan Sekolah Tinggi Ilmu Ekonomi YKPN. 
Putri, D. 2005. Hubungan Penerapan Akuntansi Pertanggungjawaban dengan Kinerja Manajer Pusat Investasi (Survei pada Perusahaan Bengkel di Bandung). www.google.com

Sekaran, U. 2006. Metode Penelitian untuk Bisnis. Jakarta: Salemba Empat.

Smith, J. L., R. M. Keith dan W. L. Stephens. 1988. Managerial Accounting.Singapore : Mc GrawHill, Inc.

Soemarso. 2004. Akuntansi: Suatu Pengantar. Jakarta: Salemba Empat.

Supriyanto, Y. 2001. Anggaran Perusahaan, Edisi ke-1. Yogyakarta : Bagian Penerbitan Sekolah Tinggi Ilmu Ekonomi YKPN.

Subiyanto , 2000 , Metodologi Penelitian Deskriptif. Penerbit Salemba Empat Jkt

Soeratno dan Lincolin Arsyad, 1999; Pengantar Metode Penelitian. STIE YKPN Yokyakarta

Trisnawati, S. 2006. Hubungan Antara Penerapan Akuntansi Pertanggungjawaban dengan Efektivitas Pengendalian Biaya (Survei pada 5 Hotel di Kota Tasikmalaya). www.google.com 